\title{
Preparation and Characterization of Thermally Stable Collagens from the Scales of Lizardfish (Synodus macrops)
}

\author{
Junde Chen * ${ }^{\mathbb{B}}$, Guangyu Wang and Yushuang Li
}

Technical Innovation Center for Utilization of Marine Biological Resources, Third Institute of Oceanography, Ministry of Natural Resources, Xiamen 361005, China; 17859733637@163.com (G.W.); liyushuang@tio.org.cn (Y.L.)

* Correspondence: jdchen@tio.org.cn; Tel./Fax: +86-0592-215527

Citation: Chen, J.; Wang, G.; Li, Y. Preparation and Characterization of Thermally Stable Collagens from the Scales of Lizardfish (Synodus macrops). Mar. Drugs 2021, 19, 597. https:// doi.org/10.3390/md19110597

Academic Editor: Sik Yoon

Received: 25 September 2021

Accepted: 19 October 2021

Published: 21 October 2021

Publisher's Note: MDPI stays neutral with regard to jurisdictional claims in published maps and institutional affiliations.

Copyright: (c) 2021 by the authors. Licensee MDPI, Basel, Switzerland. This article is an open access article distributed under the terms and conditions of the Creative Commons Attribution (CC BY) license (https:// creativecommons.org/licenses/by/ $4.0 /)$.

\begin{abstract}
Marine collagen is gaining vast interest because of its high biocompatibility and lack of religious and social restrictions compared with collagen from terrestrial sources. In this study, lizardfish (Synodus macrops) scales were used to isolate acid-soluble collagen (ASC) and pepsinsoluble collagen (PSC). Both ASC and PSC were identified as type I collagen with intact triple-helix structures by sodium dodecyl sulfate-polyacrylamide gel electrophoresis and spectroscopy. The ASC and PSC had high amino acids of 237 residues/1000 residues and 236 residues/1000 residues, respectively. Thus, the maximum transition temperature $\left(\mathrm{T}_{\max }\right)$ of ASC $\left(43.2^{\circ} \mathrm{C}\right)$ was higher than that of PSC $\left(42.5^{\circ} \mathrm{C}\right)$. Interestingly, the $\mathrm{T}_{\max }$ of both ASC and PSC was higher than that of rat tail collagen $\left(39.4^{\circ} \mathrm{C}\right)$ and calf skin collagen $\left(35.0^{\circ} \mathrm{C}\right)$, the terrestrial collagen. Solubility tests showed that both ASC and PSC exhibited high solubility in the acidic pH ranges. ASC was less susceptible to the "salting out" effect compared with PSC. Both collagen types were nontoxic to HaCaT and MC3T3-E1 cells, and ASC was associated with a higher cell viability than PSC. These results indicated that ASC from lizardfish scales could be an alternative to terrestrial sources of collagen, with potential for biomedical applications.
\end{abstract}

Keywords: lizardfish scale; marine collagen; thermal stability; cell viability

\section{Introduction}

Collagen is an important structural protein of connective tissue, and it is also a principal component of the natural extracellular matrix (ECM) that plays a dominant role in providing overall tissue stiffness and integrity [1]. The main feature of collagen is its triple helical structure. In collagen type I, this structure consists of two identical polypeptide chains, $\alpha 1$, and one polypeptide chain, $\alpha 2$, with each chain containing one or more repeating amino-acid motifs $(\mathrm{Gly}-\mathrm{X}-\mathrm{Y})$, where $\mathrm{X}$ is proline or hydroxyproline and $\mathrm{Y}$ represents any amino acid [2,3]. So far, 29 types of collagen (I-XXIX) have been identified and characterized. Among them, fibril-forming type I collagen with a high structural order and high stiffness is the most widely distributed type of collagen in connective tissue, accounting for $80-85 \%$ of collagen in the body $[4,5]$. Due to its excellent biocompatibility, low antigenicity, and high biodegradability, type I collagen is regarded as one of the promising biomaterials and is widely used in tissue engineering and the pharmaceutical and biomedical industry [6,7].

Collagen's preferred sources are the skin and tendons of bovine and porcine. However, as collagen of mammals has the risk of triggering an immune reaction and transferring zoonosis and transmissible spongiform encephalopathies, marine collagen has attracted interest in recent years [2,8]. Marine collagen has lower gelling and melting temperatures than mammalian collagen, but marine collagen is cheaper to extract and easier to prepare than mammalian collagen [8,9]. Marine collagen, such as that from sponges, jellyfish, squids, octopuses, cuttlefish, and fish skin, bone, and scales, comes from both marine vertebrates and invertebrates $[9,10]$. There is great demand for marine collagen, and 
this is now the main source of collagen globally. Sourour Addad et al. (2011) obtained collagen from Jellyfish [11], Tziveleka et al. (2017) isolated the collagen from marine sponges Axinella cannabina and Suberites carnosus [12] and skin and Cruz-López et al. (2018) extracted collagen from gulf corvina skin and swim bladder [10]. As reported in the literature, the marine collagen market is expected to reach USD 983.84 million by 2025 , with a compound annual growth rate of $7.4 \%$ [13]. Marine collagen, compared with collagen from terrestrial sources, is more easily extracted [2], has high biocompatibility [5], is without the risks of animal diseases and pathogens; has a higher absorption capacity (up to 1.5 times more efficient entry into the body), and is not associated with religious and ethical restrictions $[14,15]$. This provides an opportunity for fish scales. Namely, fish scales are the waste product from the fish processing industry, and they represent on average $2 \%$ of fish body weight [16]. The poor biodegradability of scales makes them difficult to be managed as waste [16]. However, scales are a safe and good source of marine type I collagen [17]. Therefore, the extraction of type I collagen from scales may be beneficial in terms of both economic and environmental benefits, and it could possibly drive the development of new industries. Type I collagen from scales has gained increasing interest, and scales are widely regarded as a promising source of collagen [17]. Many successful extractions of collagen from scales have been reported, including tilapia scales collagen [18], gourami scales collagen [19], and miiuy croakers scales collagen [20]. Lizardfish (Synodus macrops) is a common economic fish species in China, and there have been no studies about lizardfish scales collagen.

Therefore, in this study, we isolated collagen from lizardfish scales by using acid and enzymatic extraction methods; characterized the physicochemical properties, structural properties, and thermal stability of acid-soluble collagen (ASC) and pepsin-soluble collagen (PSC), and investigated the rheological properties, and cell viability, all of which might provide useful information for the development and application of marine collagen.

\section{Results}

\subsection{Collagen Yield}

The collagen from lizardfish scales was prepared using acid extraction and enzymatic extraction separately. The yield of ASC and PSC was $4.2 \pm 0.2 \%$ (based on a dry weight basis) and $4.7 \pm 0.1 \%$ (dry weight), respectively.

\subsection{Sodium Dodecyl Sulfate-Polyacrylamide Gel Electrophoresis (SDS-PAGE)}

The electrophoretic patterns of ASC and PSC from lizardfish scales are illustrated in Figure 1. It is clear that ASC and PSC show similar electrophoretic patterns as both consist mainly of two different types of $\alpha$-chains $(\alpha 1$ and $\alpha 2)$ and dimeric $\beta$-chains. The molecular weight of collagen was analyzed using Quantity One 4.6.0 software (Bio-Rad Laboratories, Hercules, CA, USA); we found that the molecular weight of ASC ( $\alpha 1-\mathrm{MW}, 137 \mathrm{kDa} ; \alpha 2-\mathrm{MW}$, $127 \mathrm{kDa}$ ) was slightly higher than that of PSC ( $\alpha 1-\mathrm{MW}, 135 \mathrm{kDa}$; $\alpha 2-\mathrm{MW}, 123 \mathrm{kDa}$ ), which can be attributed to the removal of telopeptide regions of the PSC [21]. The protein patterns of ASC and PSC were similar to those of the collagen obtained from tilapia skin [18] and Pacific cod skin [22]. Although pepsin removed the cross-link-containing telopeptide, the electrophoresis patterns showed that PSC contained a higher intensity of $\beta$-chains than ASC, indicating that PSC has high molecular cross-linkages [23,24]. Moreover, the ratio of $\alpha 1$ and $\alpha 2$ was calculated by Image J software (VERSION 1.8.0, National Institute of Mental Health, Bethesda, MD, USA); specifically, the ratios of $\alpha 1$ and $\alpha 2$ for ASC and PSC were 1.86 and 2.23, respectively, both close to 2:1, implying that ASC and PSC extracted from lizardfish scales are type I collagen $\left([\alpha 1]_{2} \alpha 2\right)[25]$. 


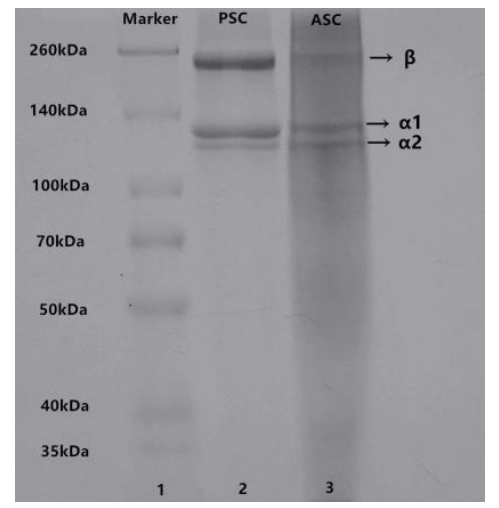

Figure 1. SDS-PAGE patterns of ASC and PSC from lizardfish scales. Lane 1: Marker standard; Lane 2: PSC; Lane 3: ASC. The experiment was conducted only once $(n=1)$.

\subsection{Spectroscopy Characterization}

\subsubsection{UV Absorption Spectrum}

Generally, collagen has a maximum absorption peak in 210-240 $\mathrm{nm}$ range, which is attributed to the presence of $\mathrm{C}=\mathrm{O},-\mathrm{COOH}$, and $\mathrm{CONH}_{2}$ groups in the polypeptide chains of collagen [23]. The UV absorption spectra of lizardfish scales collagen are shown in Figure 2a, namely, ASC and PSC showed sharp and intense maximum absorption peaks at $235 \mathrm{~nm}$ and $236 \mathrm{~nm}$, respectively, which is consistent with the UV absorption characteristics of type I collagen [25]. The aromatic residues, including tyrosine and phenylalanine, have a maximum absorption peak at $280 \mathrm{~nm}$. As shown in Figure 2a, ASC and PSC did not demonstrate a significant absorption peak at $280 \mathrm{~nm}$.

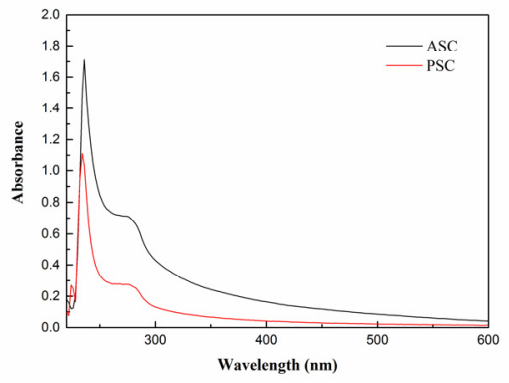

(a)

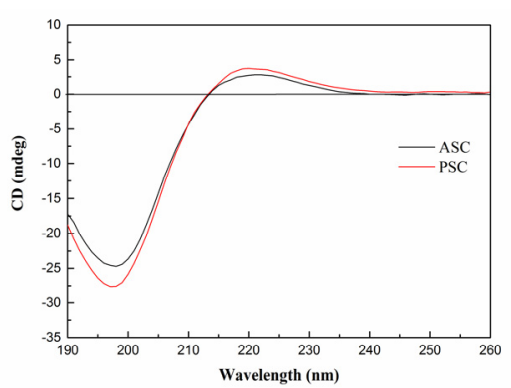

(c)

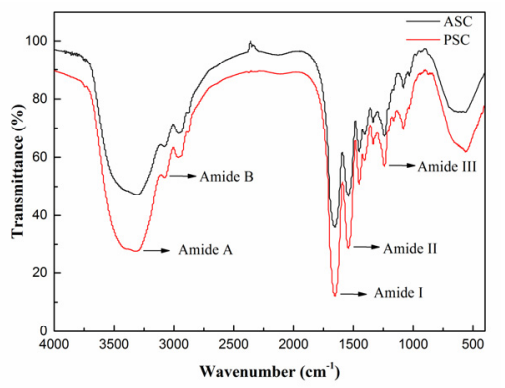

(b)

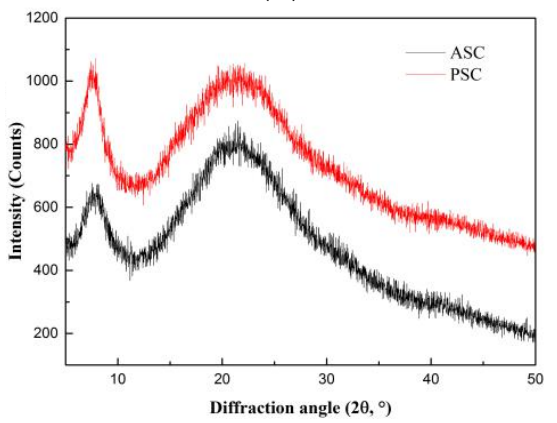

(d)

Figure 2. Spectroscopy properties of ASC and PSC. (a) UV absorption spectra, (b) Fourier transform infrared spectroscopy, (c) circular dichroism, and (d) X-ray diffraction. The experiment was conducted only once $(n=1)$.

\subsubsection{Fourier-Transform Infrared (FTIR) Spectrum}

FTIR spectra of collagen from lizardfish scales are displayed in Figure 2b. ASC and PSC from lizardfish scales contained five major characteristic absorption bands, including 
Amide A, Amide B, Amide I, Amide II, and Amide III. The Amide A band $\left(3400-3440 \mathrm{~cm}^{-1}\right)$ is mainly associated with the stretching vibration of $\mathrm{N}-\mathrm{H}$ [18]. However, the hydrogen bond formation leads to a change in wavenumber to a lower frequency [18]. The Amide $\mathrm{A}$ absorption bands of ASC and PSC were found at $3307 \mathrm{~cm}^{-1}$ and $3324 \mathrm{~cm}^{-1}$, respectively, indicating that $\mathrm{N}-\mathrm{H}$ groups were involved in the formation of hydrogen bonds, which resulted in a shift of the Amide A band to the lower frequency. The Amide B band $\left(3080 \mathrm{~cm}^{-1}\right)$ is linked to the asymmetrical stretch of $-\mathrm{CH}_{2}$. We showed that the Amide B bands of ASC and PSC were located at $3080 \mathrm{~cm}^{-1}$. In the present study, the positions of Amide I bands of ASC and PSC were found at wavenumbers of $1653 \mathrm{~cm}^{-1}$ and $1654 \mathrm{~cm}^{-1}$, respectively; Amide II bands of both ASC and PSC were located at $1542 \mathrm{~cm}^{-1}$; and Amide III bands of ASC and PSC were observed at $1240 \mathrm{~cm}^{-1}$ and $1241 \mathrm{~cm}^{-1}$, respectively. Moreover, the ratios of absorption intensities between the Amide III band and $1450 \mathrm{~cm}^{-1}$ band were approximately 1.0, confirming that the triple helical structures of ASC and PSC were well maintained [6].

\subsubsection{Circular Dichroism (CD) Spectrum}

$\mathrm{CD}$ is a simple and effective technique to identify whether the triple helical structure is intact [22]. The CD spectrum of native collagen with a triple-helix structure shows a positive peak at $221 \mathrm{~nm}$ (maximum positive cotton effect), a negative peak at $198 \mathrm{~nm}$ (maximum negative cotton effect), and a crossover point (zero rotation) at approximately $213 \mathrm{~nm}[10,22]$. As shown in Figure 2c, the CD spectrum of lizardfish scales ASC and PSC exhibited weak positive absorption peaks at $221 \mathrm{~nm}$ and $220 \mathrm{~nm}$, respectively, and negative absorption peaks were observed at $198 \mathrm{~nm}$ and $197 \mathrm{~nm}$, respectively, both with a crossover point at $213 \mathrm{~nm}$. Moreover, the Rpn values (the ratio of the positive to negative) of ASC and PSC were 0.12 and 0.14 , respectively, indicating that the collagen extracted from lizardfish scales possess a triple-helix conformation $[26,27]$.

\subsubsection{X-ray Diffraction (XRD) Spectrum}

The XRD patterns of ASC and PSC are shown in Figure 2d. We found that ASC and PSC consisted of two peaks, a sharp and a broad peak. The diffraction angles (2 $\theta$ ) of ASC were $7.86^{\circ}$ and $21.25^{\circ}$, and those of PSC were $7.58^{\circ}$ and $21.02^{\circ}$, which are consistent with the characteristic diffraction peaks of collagen [28]. The $d$ value of the first sharp peak of ASC was $11.25 \AA$, and that of PSC was $11.66 \AA$, and this reflects the distance between the molecular chains [28]. The distance between the molecular chains of PSC was greater than that within ASC, indicating weaker molecular interactions in PSC. This may be related to the cleavage of the terminal peptide sequence of collagen [29]. The $d$ value of the second relatively broad peak of ASC was $4.18 \AA$, and that of PSC was $4.23 \AA$, and this reflects the distance between their skeletons [22].

\subsection{Amino Acid Composition}

The amino acid compositions of the lizardfish scales ASC and PSC are shown in Table 1. It can be seen that glycine was the abundant amino acid in collagen, with ASC and PSC containing $35.1 \%$ and $34.9 \%$ of glycine, respectively. Similar results were found in the giant groaker skin collagen [30] and the Pacific cod skin collagen [22]. The results are consistent with glycine, which is identical in that in the collagen polypeptide chain, the repeating (Gly-X-Y)n assembles into a triple helix structure [30]. Alanine and proline accounted for 161 residues/1000 residues and 159 residues/1000 residues, and 158 residues/1000 residues and 157 residues/1000 residues in ASC and PSC, respectively. In addition, both the ASC and PSC were devoid of cysteine and tryptophan. Further, the amino acid (proline and hydroxyproline) contents of the ASC and PSC were 237 residues/1000 residues and 236 residues / 1000 residues, respectively. 
Table 1. Amino acid composition of the ASC and PSC from lizardfish scales. The results are expressed as residues $/ 1000$ total amino acid residues. Values represent the means \pm standard deviations (SD) of duplicate assays $(\mathrm{n}=3)$.

\begin{tabular}{ccc}
\hline Amino Acid & ASC & PSC \\
\hline Aspartic acid & $15 \pm 1$ & $16 \pm 2$ \\
Glutamine acid & $13 \pm 1$ & $11 \pm 1$ \\
Serine & $50 \pm 2$ & $51 \pm 2$ \\
Histidine & $7 \pm 1$ & $7 \pm 2$ \\
Glycine & $351 \pm 19$ & $349 \pm 21$ \\
Threonine & $29 \pm 2$ & $30 \pm 3$ \\
Arginine & $15 \pm 1$ & $14 \pm 1$ \\
Alanine & $161 \pm 11$ & $159 \pm 14$ \\
Tyrosine & $5 \pm 1$ & $5 \pm 1$ \\
Valine & $25 \pm 2$ & $26 \pm 1$ \\
Methionine & $8 \pm 1$ & $7 \pm 1$ \\
Phenylalanine & $11 \pm 2$ & $12 \pm 1$ \\
Isoleucine & $8 \pm 2$ & $10 \pm 2$ \\
Leucine & $26 \pm 3$ & $25 \pm 1$ \\
Lysine & $35 \pm 4$ & $37 \pm 2$ \\
Proline & $158 \pm 9$ & $157 \pm 7$ \\
Hydroxylysine & $4 \pm 1$ & $5 \pm 1$ \\
Hydroxyproline & $79 \pm 9$ & $79 \pm 7$ \\
Total & 1000 & 1000 \\
Proline + Hydroxyproline & $237 \pm 16$ & $236 \pm 14$ \\
\hline
\end{tabular}

\subsection{Morphology Characterization}

The morphology of collagen is vital for assessing its potential application in biomedicine [31] The collagen solution obtained from lizardfish scales was lyophilized, and the morphology of collagen sponges was observed by scanning electron microscopy (SEM) (Figure 3). As shown in Figure $3 a, a^{\prime}$, ASC and PSC were observed as white sponges with loose, uniform, and porous structures observed by the naked eye. ASC and PSC surfaces under SEM were partially wrinkled, which may be attributed to water being sublimated during the freezedrying process [32]. The SEM images showed that ASC and PSC had a similar multilayer overlapping and porous microstructure. However, there were some differences in the structure between ASC and PSC under SEM observation. As observed at a magnification of $400 \times$, ASC exhibited a compact sheet and porous structure (Figure 3b), while PSC had a loose and large sheet structure (Figure $3 b^{\prime}$ ); ASC exhibited a more porous structure than PSC. It was clearly visible at higher magnifications $(800 \times)$ that ASC had considerable fibrillary structure and a small number of sheet structures (Figure 3c), while PSC had large sheet-like film structures (Figure 3c').

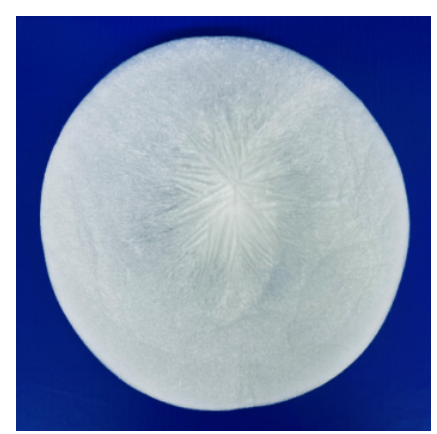

(a)

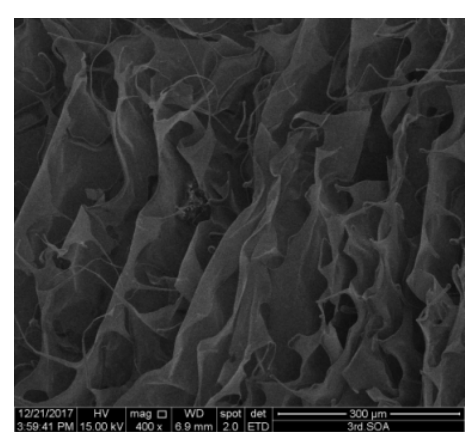

(b)

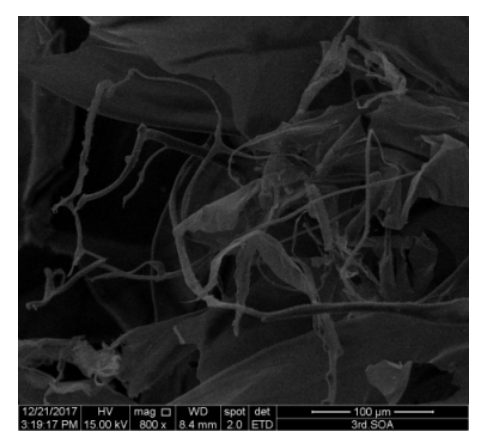

(c)

Figure 3. Cont. 


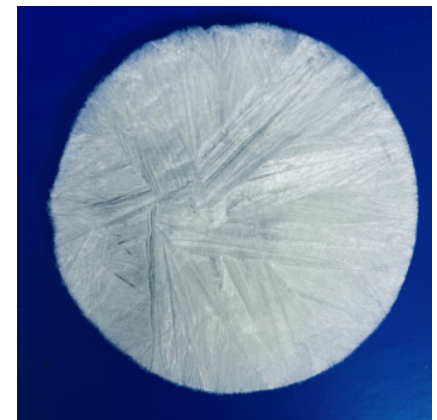

$\left(\mathbf{a}^{\prime}\right)$

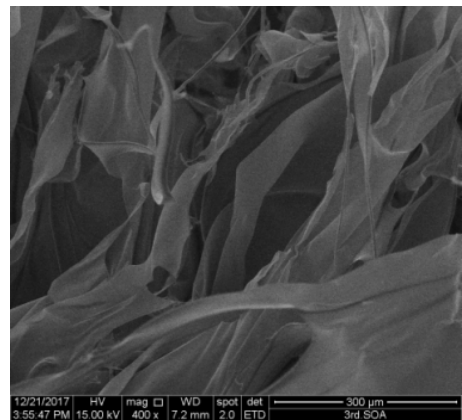

$\left(\mathbf{b}^{\prime}\right)$

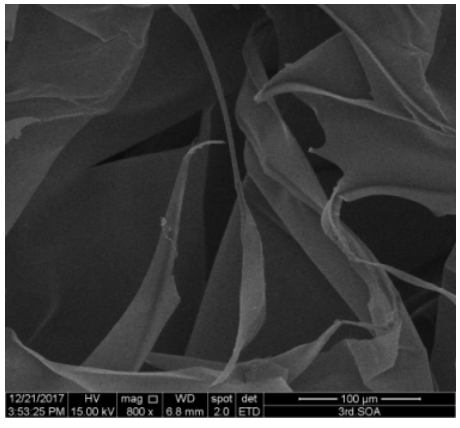

$\left(\mathbf{c}^{\prime}\right)$

Figure 3. SEM images of ASC and PSC. (a) ASC, (b) ASC at 400 $\times$ magnification, (c) ASC at $800 \times$ magnification, (a') PSC, $\left(\mathbf{b}^{\prime}\right)$ PSC at $400 \times$ magnification, and $\left(\mathbf{c}^{\prime}\right)$ PSC at $800 \times$ magnification. The experiment was done only once $(n=1)$.

\subsection{Thermal Stability}

Differential scanning calorimetry (DSC) was used to measure the maximum transition temperature $\left(\mathrm{T}_{\max }\right)$ of collagen. The DSC curves of collagen from the lizardfish scales are shown in Figure 4. It was observed that the $\mathrm{T}_{\max }$ of collagen from lizardfish scales was higher than that of rat tail collagen. The $\mathrm{T}_{\max }$ values of rat tail collagen, ASC, and PSC were $39.4{ }^{\circ} \mathrm{C}, 43.2{ }^{\circ} \mathrm{C}$, and $42.5^{\circ} \mathrm{C}$, respectively. The $\mathrm{T}_{\max }$ of ASC was higher than PSC and the rat tail collagen, and the $\Delta \mathrm{H}$ of ASC $(0.981 \mathrm{~J} / \mathrm{g})$ was also higher than the PSC $(0.711 \mathrm{~J} / \mathrm{g})$ and the rat tail collagen $(0.680 \mathrm{~J} / \mathrm{g})$.

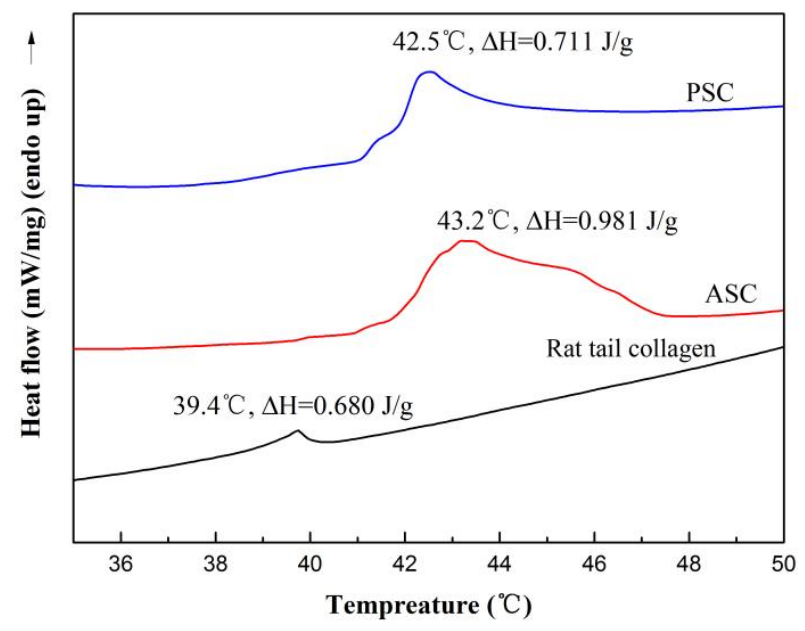

Figure 4. The DSC curve of ASC and PSC. The experiment was performed only once $(n=1)$.

\subsection{Solubility}

\subsubsection{The Influence of $\mathrm{pH}$ on the Solubility of Collagen Solutions}

The relative solubility of ASC and PSC extracted from the scale of lizardfish at different $\mathrm{pH}$ showed similar trends, as shown in Figure 5a. ASC and PSC exhibited higher relative solubility in the very acidic $\mathrm{pH}$ range (1-4), and both ASC and PSC showed the maximum relative solubility at $\mathrm{pH}$ 2. The relative solubility of ASC and PSC decreased with increasing $\mathrm{pH}$, and a sharp decrease in relative solubility of ASC and PSC occurred at $\mathrm{pH}$ above 5 and 4 , and the minimum relative solubility was $11.09 \%$ and $7.70 \%$, respectively. The isoelectric points (pI) of ASC and PSC were approximately around 7 and 8, respectively [33]. 


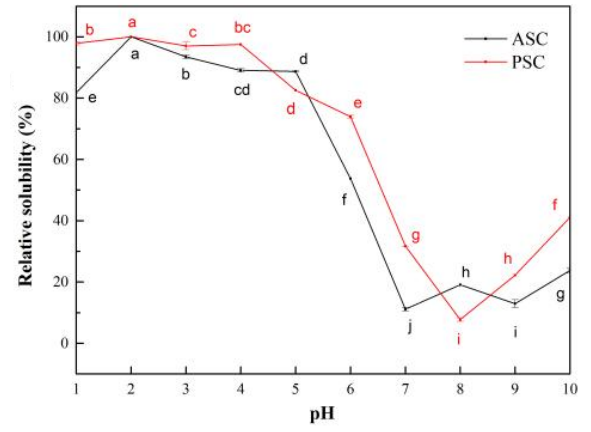

(a)

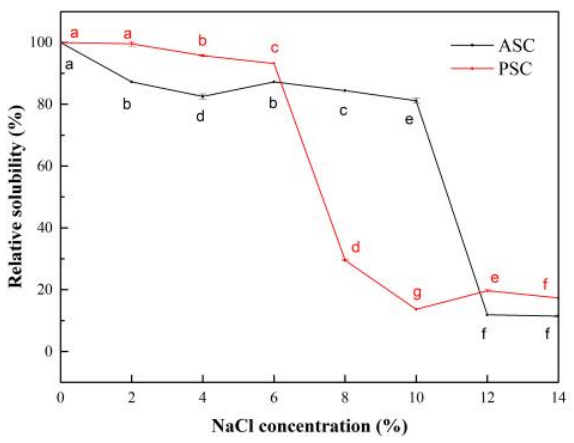

(b)

Figure 5. Relative solubility of ASC and PSC. (a) Effect of $\mathrm{pH}$; (b) effect of $\mathrm{NaCl}$ concentration. Values represent the means \pm standard deviations (SD) of duplicate assays $(n=3)$. Different letters indicated significant differences between the samples.

\subsubsection{The Influence of $\mathrm{NaCl}$ Concentration on the Solubility of Collagen Solutions}

The effect of $\mathrm{NaCl}$ concentration on the relative solubility of ASC and PSC from lizardfish scales is shown in Figure 5b. ASC and PSC showed high relative solubility at low $\mathrm{NaCl}$ concentrations, both above $80 \%$. The relative solubility of ASC and PSC from lizardfish scales decreased with increasing $\mathrm{NaCl}$ concentrations, with the lowest values at $14 \%$ and $10 \%$ and $11.42 \%$ and $13.64 \% \mathrm{NaCl}$ concentrations, respectively. Subsequently, as the $\mathrm{NaCl}$ concentration increased, the relative solubility of collagen remained relatively stable but very low (around 20\%).

\subsection{Rheological Properties}

The frequency dependence of the rheological parameters elastic modulus $\left(\mathrm{G}^{\prime}\right)$ and viscous modulus $\left(\mathrm{G}^{\prime \prime}\right)$ from lizardfish scales ASC and PSC was assessed using dynamic frequency scan tests. The $\mathrm{G}^{\prime}$ was defined as the elasticity of protein, and $\mathrm{G}^{\prime \prime}$ was defined as the viscous behavior of the protein [34]. Figure 6 exhibits the dynamic frequency sweep tests of ASC and PSC, and the $\mathrm{G}^{\prime}$ and $\mathrm{G}^{\prime \prime}$ values of ASC and PSC showed an increasing trend as the frequency increased from 0.01 to $10 \mathrm{~Hz}$. The $\mathrm{G}^{\prime}$ and $\mathrm{G}^{\prime \prime}$ values of PSC are higher than the corresponding $\mathrm{G}^{\prime}$ and $\mathrm{G}^{\prime \prime}$ values of ASC between 0.01 and $10 \mathrm{~Hz}$. As shown in Figure 6a, the increase in the $\mathrm{G}^{\prime}$ value of PSC was higher than that of ASC in the test frequency range $0.01-10 \mathrm{~Hz}$.

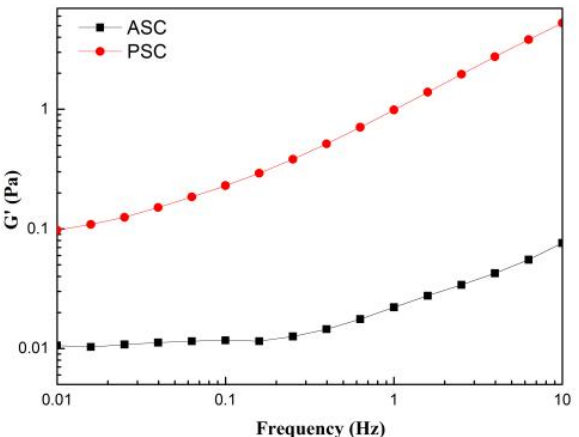

(a)

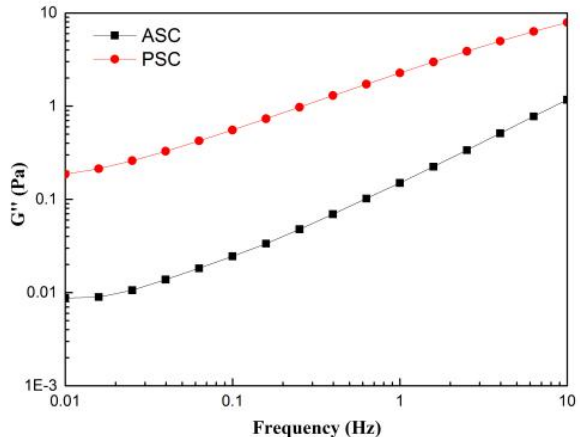

(b)

Figure 6. Rheological behavior of collagens solution (a) storage modulus $\left(G^{\prime}\right)$; (b) loss modulus $\left(G^{\prime \prime}\right)$. The experiment was performed only once $(n=1)$.

\subsection{Cell Compatibility}

The cytotoxicity of the HaCaT (Cat No. CBP60331) and MC3T3-E1 (Cat No. CBP60946) cells lines on lizardfish scales collagen after $24 \mathrm{~h}$ and $48 \mathrm{~h}$ was investigated using a CCK-8 assay. The results of relative cell viability are shown in Figure 7. After $24 \mathrm{~h}$ of cell culture, the 
relative viability of the HaCaT cells on ASC and PSC were $107.18 \pm 1.78 \%$ and $101.44 \pm 3.62 \%$, respectively, and for the MC3T3-E1 cells, $113.43 \pm 2.40 \%$ and $105.95 \pm 1.90 \%$, respectively. Moreover, the relative viability of $\mathrm{HaCaT}$ cells on ASC and PSC were $111.78 \pm 1.74 \%$ and $106.45 \pm 1.89 \%$, respectively, and for the MC3T3-E1 cells, $117.80 \pm 1.65 \%$ and $110.64 \pm 2.70 \%$, respectively, after $48 \mathrm{~h}$. The relative viability of the HaCaT and MC3T3-E1 cells on ASC and PSC increased during $48 \mathrm{~h}$ of cell culture. Moreover, the morphology of cells was observed under an inverted microscope, and there were no observable changes in the $\mathrm{HaCaT}$ and MC3T3-E1 cells compared to the control group (Figure 8).

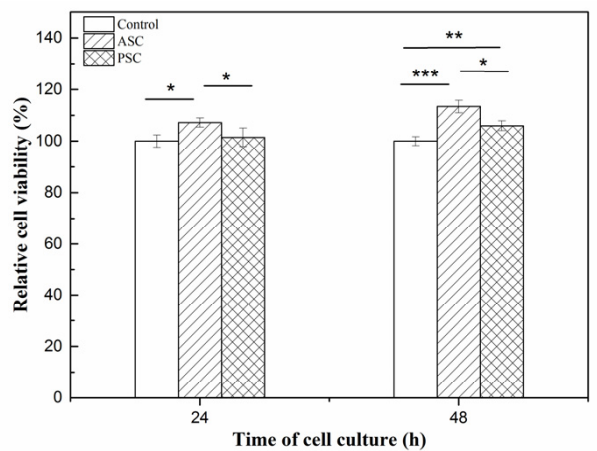

(a)

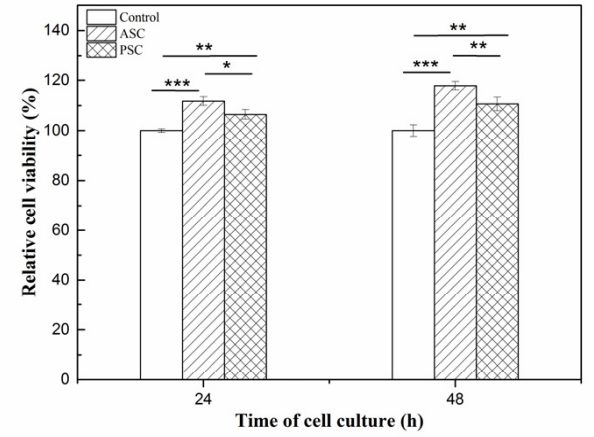

(b)

Figure 7. Relative cell viability of HaCaT and MC3T3-E1 cells after $24 \mathrm{~h}$ and $48 \mathrm{~h}$ of incubation in ASC and PSC. (a) is HaCaT cells; (b) is MC3T3-E1 cells. Values represent the means \pm standard deviations (SD) of duplicate assays $(\mathrm{n}=6) .{ }^{*} p<0.5,{ }^{* *} p<0.01,{ }^{* * *} p<0.001$.

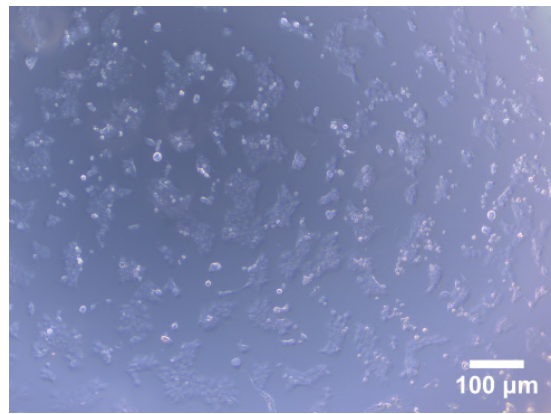

(a1)

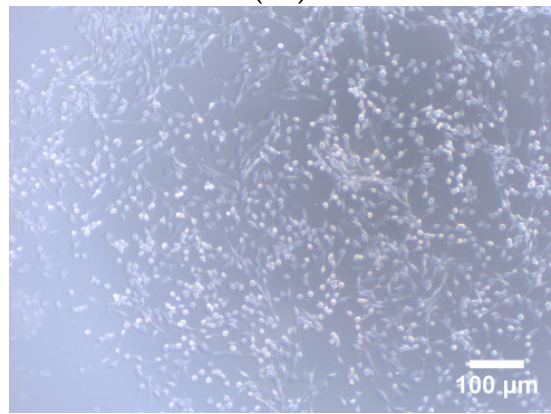

(b1)

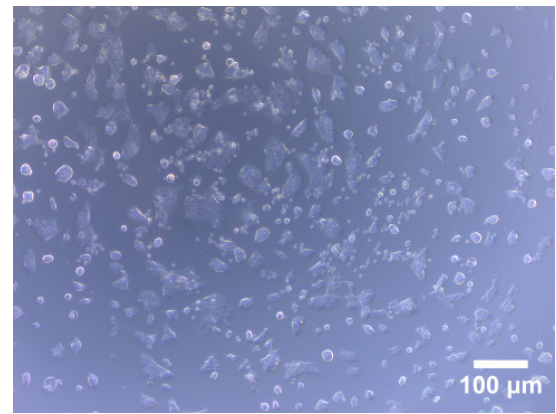

(a2)

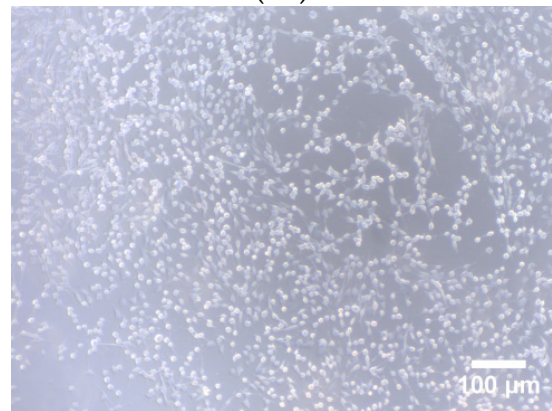

(b2)

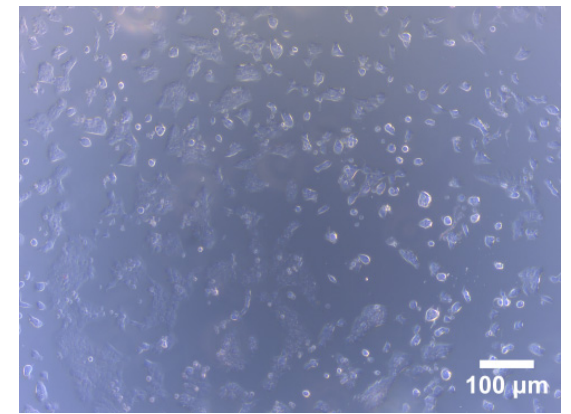

(a3)

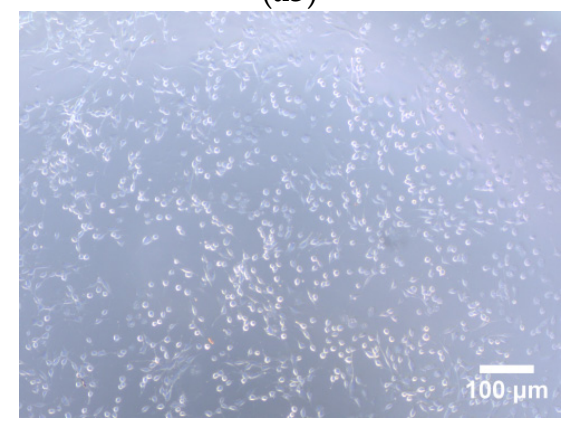

(b3)

Figure 8. Cont. 


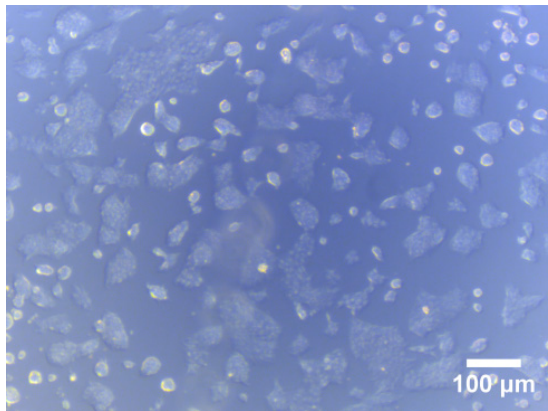

(c1)

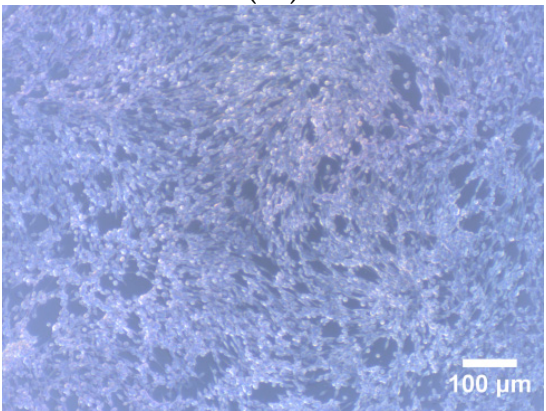

(d1)

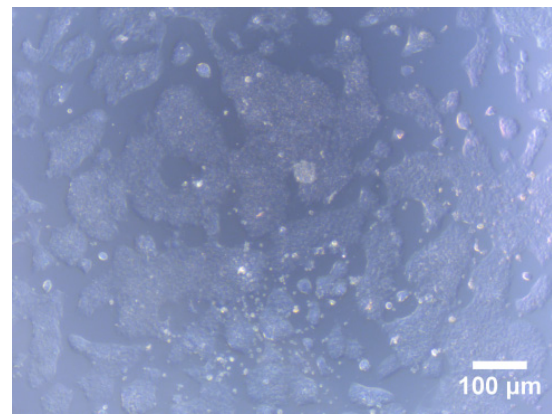

(c2)

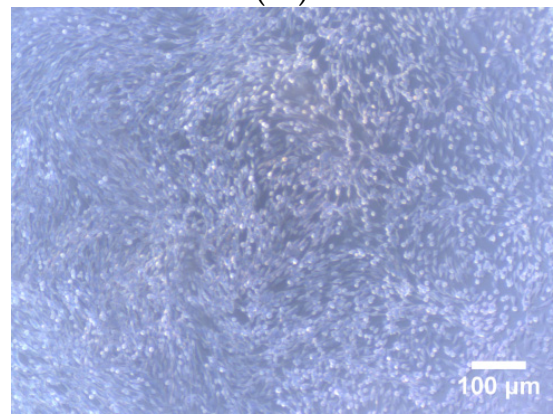

(d2)

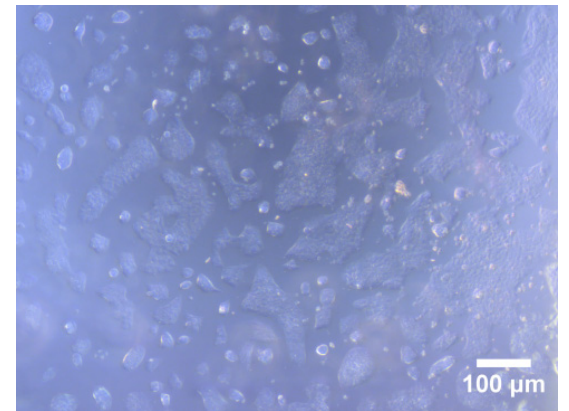

(c3)

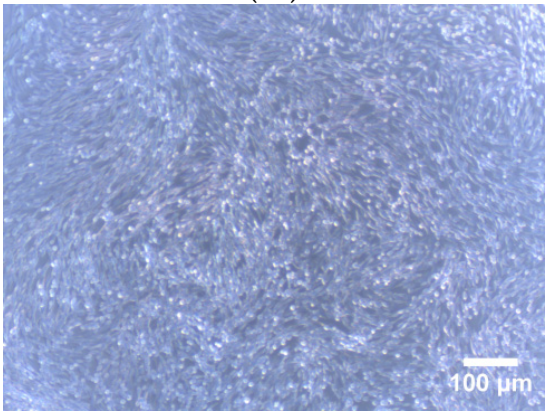

(d3)

Figure 8. Morphology of HaCaT and MC3T3-E1 cells on lizardfish scales collagens $(40 \times$ magnifications). (a1-a3) HaCaT cells for $24 \mathrm{~h}$ cell culture, (a1) is control, (a2) is ASC, and (a3) is PSC; (b1-b3) MC3T3-E1 cells for 24 h cell culture, (b1) is control, (b2) is ASC, (b3) is PSC; (c1-c3) HaCaT cells for 48 h cell culture, (c1) is control, (c2) is ASC, and (c3) is PSC; (d1-d3) MC3T3-E1 cells for $48 \mathrm{~h}$ cell culture, (d1) is control, (d2) is ASC, and (d3) is PSC.

\section{Discussion}

Collagen is an important and diverse biopolymer that has seen a significant increase in applications in food, medicine, cosmetics, and tissue engineering [35] with the highest structural order and the greatest stiffness, is widely used in materials for biomedical applications [36]. Marine collagen has been successfully isolated from marine by-products $[1,37,38]$. There are no reports on the use of lizardfish scales for collagen preparation.

In the present study, we isolated type I collagen from lizardfish scales by using acid and enzymatic extraction methods. It was found that the use of pepsin increased the yield of the collagen extraction, and this could be attributed to the fact that pepsin cleaves the crosslinked molecules in the telopeptide region, leading to further extraction with increased yield. This made the extraction yield of PSC higher than that of ASC. These results agreed with those of Keawdang et al. (2014), who reported that ASC and PSC from yellowfin tuna swim bladders were extracted with yields of $1.07 \%$ and $12.10 \%$, respectively [38], and Matmaroh et al. (2011), who reported that ASC and PSC from spotted golden goatfish were extracted with yields of $0.46 \%$ and $1.20 \%$, respectively [39]. The difference in the extraction yields could be attributed to the varying cross-linking of collagen fibrils in the different raw materials. In this study, the collagen yields from lizardfish scales were higher than that from bighead carp scales (2.7\%) and spotted golden goatfish scales (ASC $0.46 \%$ and PSC $1.20 \%$ ). Both the ASC and PSC had similar UV absorption spectra to those of soft-shelled turtle collagen [23], carp scales collagen [37], and red stingray skin collagen [25]. In addition, we also studied the infrared spectra of the ASC and PSC, and the infrared spectra of the ASC and PSC were similar to the spectra of type I collagen from tilapia skin and scales [18], giant salamander skin [33], and silver carp skin [6], where the Amide I band (1600-1700 $\mathrm{cm}^{-1}$ ) typically corresponds to the stretching vibration of $\mathrm{C}=\mathrm{O}$ along the protein polypeptide backbone. This can be used as a positive marker for peptide secondary structure, and therefore it is often used in the analysis [37]. The Amide II band (1500-1600 $\mathrm{cm}^{-1}$ ) commonly arises from $\mathrm{N}-\mathrm{H}$ bending coupled with $\mathrm{C}-\mathrm{N}$ stretching vibrations [40]. The Amide III band (1200-1300 $\left.\mathrm{cm}^{-1}\right)$ arises due to C-N stretching and 
$\mathrm{N}-\mathrm{H}$ in-plane bending from amide linkages, and this is the standard confirming presence of the triple-helical structures of collagen [17]. The absorption peaks of the Amide A band of PSC showed a higher wavenumber than those of the ASC, suggesting that fewer $\mathrm{N}-\mathrm{H}$ groups in PSC were involved in hydrogen bonding in the polypeptide chain. Similar results were found in chicken feet collagen [41]. It has also been reported in the literature that the hydrolysis of telopeptide by pepsin might increase the free amino group, and this may have led to the higher wavenumber of PSC [40,42]. Moreover, the results of the CD spectrum obtained from the ASC and PSC was similar to the CD spectrum of gulf corvina collagen (positive absorption peaks at $221 \mathrm{~nm}$ and negative absorption peaks at $198 \mathrm{~nm}$ ) [10], Perinereis nuntia cuticle collagen (positive absorption peaks at $221 \mathrm{~nm}$ and negative absorption peaks at $199 \mathrm{~nm}$ ) [28], and Nile tilapia skin collagen (positive absorption peaks at $221 \mathrm{~nm}$ and negative absorption peaks at $197 \mathrm{~nm}$ ) [16]. In addition, the XRD spectrum analysis showed that the distance between the molecular chains and the distance between their skeletons of the ASC and PSC were similar to the Pacific cod skin collagen [22] and the cuticle of the Perinereis nuntia collagen [28]. The results of the FTIR, $\mathrm{CD}$, and XRD indicated that both the ASC and PSC had a native triple helix conformation, and that the acid and enzymatic extraction methods of collagen had no adverse effects on the molecular integrity of the collagen. The highly porous structure is an important feature of biomedical materials that can influence cell seeding, migration, growth, and other physiological activities [28]. The morphology results suggested that ASC and PSC from lizardfish scales have the potential for biomedical materials [41].

The pyrrolidone ring formed by the amino acids facilitates the strengthening of the triple helix structure of collagen, and this is directly linked to thermal stability and is one feature that determines the potential use of collagen. An analysis of the amino acid content showed that the ASC and PSC had higher amino acid contents than that of the grass carp skin collagen (186 residues/1000) [43], the spotted golden goatfish collagen (ASC 186 residues/1000 and PSC 189 residues/1000, respectively) [39], and the calf skin collagen (221 residues/1000) [44]. Therefore, collagen extracted from the lizardfish scales may have high thermal stability based on the amino acid analysis. Thus, we further characterized the thermal stability of the collagen. In general, collagen obtained from fish species that live in cold environments is often less thermal stable than collagen from fish species that live in warmer environments [39]. The lizardfish (S. macrops) is widely distributed in tropical and subtropical waters [45], and the $T_{\max }$ of lizardfish scale collagen is similar to that of spotted golden goatfish scale collagen (ASC $41.58{ }^{\circ} \mathrm{C}$, PSC $41.01{ }^{\circ} \mathrm{C}$ ), a common and abundant species in tropical and sub-tropical regions [39]. In addition, it is higher than cold-water species arabesque greenling skin collagen (ASC $15.7^{\circ} \mathrm{C}$ and PSC $15.4^{\circ} \mathrm{C}$, respectively) [46] and temperate-water fishes grass carp skin collagen $\left(28.4^{\circ} \mathrm{C}\right)$ [43]. These results were consistent with the results previously reported, indicating that the collagen obtained from the fish species living in cold environments often had lower hydroxyproline contents exhibited less thermal stability than collagen from fish species living in warmer environments [39]. These results were consistent with the amino acid composition of the above studies, with lizardfish scales collagen containing a higher total amino acid content (ASC 237 residues /1000 residues and 236 residues /1000 residues) than arabesque greenling skin collagen (ASC 159 residues/1000 and PSC 157 residues/1000, respectively) [46] and grass carp skin collagen (186 residues/1000 residues) [43]. Thermal stability is one of the most important properties that determine the potential applications of collagen, and it is related to the total amino acid content, habitat temperature, and body temperature [1]. In addition, the $\mathrm{T}_{\max }$ of lizardfish scale collagen was also higher than calf skin collagen $\left(35.0^{\circ} \mathrm{C}\right)[44]$, a collagen from terrestrial sources, and this indicated that collagen from lizardfish scales has the potential for use as an alternative source of terrestrial collagen.

The study of the effect of the $\mathrm{NaCl}$ concentration and $\mathrm{pH}$ on the relative solubility of collagen can provide useful information for collagen preparation as well as for processing and application. When collagen is used as a source in production in moisturizing cosmetics, solubility is a major determinant. This is because the hydrolyzed substances are used for 
cosmetic and medical cream formulations in this industry [47]. The ASC and PSC solutions exhibited the lowest solubility at $\mathrm{pH} 7$ and $\mathrm{pH} 8$, respectively, and this was attributed to the $\mathrm{pI}$ of protein with the total net charge of protein molecules being zero when the $\mathrm{pH}$ of the solution is equal to the $\mathrm{pI}[6,48]$. In this case, the hydrophobic interaction between collagen molecules is enhanced, leading to aggregation and precipitation of the protein, thereby leading to the low solubility of the solution [21,37]. In contrast, as the solution $\mathrm{pH}$ increases above the $\mathrm{pI}$, the net negatively charged residues of the protein increase, causing the ASC and PSC to display a slight increase in solubility at $\mathrm{pH}$ levels above 7 and 8 , respectively. The differences in the relative solubility of collagen at varying $\mathrm{pH}$ levels are related to the molecular properties and conformation of collagen [38]. Kaewdang et al. (2014) [38] reported that the difference in the relative solubility of ASC and PSC at different pHs may be due to the removal of telopeptide regions that affect the protonation or deprotonation of charged amino and carboxyl groups, and this may affect the repulsion of molecules associated with different solubilities. Moreover, the effect of the $\mathrm{NaCl}$ concentration on the solubility of collagen solutions showed that the relative solubility of the PSC solutions decreased sharply above a $6 \% \mathrm{NaCl}$ concentration, while the ASC solutions maintained a high relative solubility (greater than $80 \%$ ). The relative solubility of the ASC solutions decreased sharply until the $\mathrm{NaCl}$ concentration was greater than $10 \%$. The relative solubility of the collagen solutions decreased as the concentration of $\mathrm{NaCl}$ increased, and this may have been due to the protein precipitation and salting-out effect [21]. Jongjareonrak et al. (2005) [49] explained that the addition of salt increases the ionic strength and enhances the hydrophobic interaction between protein chains, resulting in a decrease in the solubility of collagen solutions. Thus, the ASC might be less susceptible to the "salting out" effect compared to the PSC [50]. A similar phenomenon has been found in giant croaker swim bladder collagen [48] and silver carp skin [6].

The results of the dynamic frequency scan test revealed that the preparation method markedly affects the rheological parameters, $\mathrm{G}^{\prime}$ and $\mathrm{G}^{\prime \prime}$, of ASC and PSC extracted from lizardfish scales. An analysis of the frequency dependence of $G^{\prime}$ and $G^{\prime \prime}$ suggested that the elasticity of the PSC had a greater dependence on frequency than that of the ASC, while the viscosity of the ASC had a greater dependence on frequency than that of the PSC. Moreover, it was noted that the $G^{\prime}$ and $G^{\prime \prime}$ values of PSC were higher than the corresponding $G^{\prime}$ and $G^{\prime \prime}$ values of ASC between 0.01 and $10 \mathrm{~Hz}$ (Figure 6), and these were similar to the collagen from chicken feet. In addition, the $G^{\prime}$ and $G^{\prime \prime}$ of PSC were higher than those of ASC at a scan frequency range of $0.2-10 \mathrm{~Hz}$ [41], suggesting that the PSC exhibited good viscoelasticity. It was also observed that $G^{\prime \prime}$ was higher than $G^{\prime}$ for all of the collagen, indicating a greater contribution of viscosity than elasticity in the ASC and PSC from lizardfish scales.

The CCK-8 assay was used to determine the viability of live cells. The relative viability of the HaCaT and MC3T3-E1 cells on the ASC and PSC were greater than 70\% during the $48 \mathrm{~h}$ of cell culture, indicating that the ASC and PSC from lizardfish scales are not toxic to HaCaT and MC3T3-E1 cells [6]. However, the relative viability of the HaCaT and MC3T3-E1 cells increased during the $48 \mathrm{~h}$ of cell culture, suggesting that the lizardfish scales collagen had the ability to promote cell proliferation. And the relative viability of the HaCaT and MC3T3-E1 cells were both higher on ASC than PSC $(p<0.05)$. These results suggested that the ASC was associated with higher cell viability than PSC. Moreover, a morphological examination of the cells showed that both the HaCaT and MC3T3-E1 cells had similar cell growth patterns as the control groups over the culture period (Figure 8). Thus, the results suggested that lizardfish scales ASC and PSC can be used as non-toxic materials in the biomedical field.

\section{Materials and Methods}

4.1. Materials

Type I collagen from rat tail and protein markers $(26,634)$ were purchased from Sigma Chemical Co. (St. Louis, MO, USA). Sodium dodecyl sulphate (SDS), Coomassie Brilliant 
Blue R-250, and N,N,N', $\mathrm{N}^{\prime}$-tetramethylethylenediamine (TEMED) were obtained from BioRad Laboratories (Hercules, CA, USA). HaCaT cell line (Cat No. CBP60331) and MC3T3-E1 cell line (Cat No. CBP60946) were provided by Cobioer (Nanjing, Chian). All chemicals were of analytical grade.

\subsection{Preparation of Collagen}

Collagen extraction from lizardfish scales was in accordance with the method of Chen et al. (2019) [29] with slight modifications. Lizardfish scales were purchased from a food processing factory in Zhangzhou, Fujian Province, China. The scales were cleaned several times with water to remove bones, spines, shellfish, shrimp feet, and offal, and then dried naturally indoors and stored at $-20^{\circ} \mathrm{C}$ until use. To remove noncollagenous proteins and pigments from the scales, the scales were soaked in $0.1 \mathrm{M} \mathrm{NaOH}$ at a ratio of $1: 8(w / v)$ at $4{ }^{\circ} \mathrm{C}$. The mixture was continuously stirred for $12 \mathrm{~h}$ (EUROSTAR 20 digital, IKA, Germany), with $0.1 \mathrm{M} \mathrm{NaOH}$ solution being changed every $6 \mathrm{~h}$. The scales residues were washed with cold distilled water until the $\mathrm{pH}$ was neutral. Thereafter, the scales residues were treated with a ratio of 1:10 $(w / v)$ of $0.5 \mathrm{M} \mathrm{Na}{ }_{2}$ EDTA $(\mathrm{pH} 7.5)$ for $24 \mathrm{~h}$ under stirring, changing the solution at an interval of $6 \mathrm{~h}$. The decalcified materials were washed with cold distilled water to achieve the neutral $\mathrm{pH}$ and dried, followed by crushing under liquid nitrogen. The samples were then stored at $-20^{\circ} \mathrm{C}$ until further processing of collagen extraction.

Pretreated scales' samples were extracted with $0.5 \mathrm{M}$ acetic acid at ratio of 1:10 (w/v) for $24 \mathrm{~h}$ under stirring to obtain ASC, while PSC was obtained by extracting with $0.5 \mathrm{M}$ acetic acid $(1: 10, w / v)$ containing $1 \%$ (pepsin 1:3000) pepsin for $24 \mathrm{~h}$. The two suspensions were centrifuged at $14,334 \times g$ for $30 \mathrm{~min}$ at $4{ }^{\circ} \mathrm{C}$ using an Avanti J-26 XP centrifuge (Beckman Coulter, Inc., Brea, CA, USA), and the collagen in the supernatant was precipitated by adding $\mathrm{NaCl}$ to the final concentration of $2.5 \mathrm{M}$. After stirring for $2 \mathrm{~h}$, the precipitates were collected by centrifugation at $14,334 \times \mathrm{g}$ for $30 \mathrm{~min}$ at $4{ }^{\circ} \mathrm{C}$. The precipitates were dissolved in $0.5 \mathrm{M}$ acetic acid at a ratio of 1:20 (w/v) and dialyzed (molecular weight cutoff: $10 \mathrm{kDa}$, MD 77 MM, Viskase, Lombard, IL, USA) against 40 volumes of $0.1 \mathrm{M}$ acetic acid for $24 \mathrm{~h}$, and then dialyzed against 40 volumes of cold distilled water for $48 \mathrm{~h}$; the dialysis water was changed every $6 \mathrm{~h}$. All of the procedures were carried at $4^{\circ} \mathrm{C}$. The dialyzed solution was freeze-dried (Telstar, lyoobeta-25, Spain) and stored at $-40{ }^{\circ} \mathrm{C}$.

The yield of collagen was calculated using the following equation:

$$
\text { Yield }(\%)=\frac{\mathrm{m}_{1}}{\mathrm{~m}_{2}} \times 100
$$

where $m_{1}$ is the weight of lyophilized collagen, and $m_{2}$ is the dry scales weight after pretreatment.

\subsection{SDS-PAGE Characterization}

The SDS-PAGE of the sample was conducted in accordance with the method of Laemmli (1970) [51] with slight modifications. The samples $(2 \mathrm{mg} / \mathrm{mL})$ were dissolved in cold distilled water and mixed at a $4: 1 \mathrm{v} / \mathrm{v}$ ratio with sample loading buffer $(277.8 \mathrm{mM}$ Tris- $\mathrm{HCl}$, pH 6.8, 44.4\% (v/v) glycerol, 4.4\% SDS, and 0.02\% bromophenol blue), followed by boiling for $10 \mathrm{~min}$. Then, $10 \mu \mathrm{L}$ of the samples' solution was loaded onto a gel consisting of $7.5 \%$ separating gel and 3\% stacking gel at a constant voltage of $110 \mathrm{~V}$ for electrophoresis (Bio-Rad Laboratories, Hercules, CA, USA). After electrophoresis for $90 \mathrm{~m}$, the gel was soaked using a solution consisting of 50\% (v/v) methanol and 10\% $(v / v)$ acetic acid followed by staining with $0.125 \%$ Coomassie Brilliant Blue R-250 that contained 50\% (v/v) methanol and $10 \%(v / v)$ acetic acid. The gel was finally destained with a mixture of $50 \%(v / v)$ ethanol and $10 \%(v / v)$ acetic acid for $30 \mathrm{~m}$. The Marker of 46,634 was used to estimate the molecular weight of the collagen, and the type I collagen from rat tail was used as standard. 


\subsection{Spectral Characterization}

\subsubsection{UV Spectrum}

The lyophilized collagen was dissolved in $0.5 \mathrm{M}$ acetic acid to produce a $1 \mathrm{mg} / \mathrm{mL}$ sample solution, followed by centrifugation at $9729 \times \mathrm{g}$ for $5 \mathrm{~min}$ at $4{ }^{\circ} \mathrm{C}$ (Neofuge $15 \mathrm{R}$, Shanghai Lishen Scientific Equipment Co., Ltd., Shanghai, China). The supernatant was analyzed by UV-visible spectrophotometer (UV-2550 Spectrophotometer, Shimadzu, Japan) at a wavelength range of $600-190 \mathrm{~nm}$ with a scan speed of $400 \mathrm{~nm} \mathrm{~min}{ }^{-1}$ with a data interval of $1 \mathrm{~nm}$ per point. The baseline was set with $0.5 \mathrm{M}$ acetic acid.

\subsubsection{FTIR}

The infrared spectrum of the samples was obtained by using a Bruker FTIR spectrophotometer (VERTEX 70, Bruker, Karlsruhe, Germany) at room temperature. The samples (lyophilized collagen) were mixed with $\mathrm{KBr}$ by grinding at the ratio of 1:100 $(w / w)$. The wavelength range was $4000-400 \mathrm{~cm}^{-1}$, with a resolution of $4 \mathrm{~cm}^{-1}$. The signals were collected automatically in 32 scans and ratioed against a background spectrum recorded from $\mathrm{KBr}$.

\subsection{3. $\mathrm{CD}$}

The samples were dissolved in precooled $0.5 \mathrm{M}$ acetic acid to obtain a final concentration of $0.1 \mathrm{mg} / \mathrm{mL}$. The sample solutions were centrifuged at $14,010 \times \mathrm{g}$ for $10 \mathrm{~min}$ at $4{ }^{\circ} \mathrm{C}$ (Neofuge 15R, Shanghai Lishen Scientific Equipment Co., Ltd., Shanghai, China), and then the supernatants were measured using a CD spectropolarimeter (Chirascan, Applied Photophysics Ltd., Leatherhead, UK). The spectrum was recorded at 260-190 nm wavelengths at $15^{\circ} \mathrm{C}$ in $0.1 \mathrm{~nm}$ steps with a response time of $1 \mathrm{~s}$.

\subsubsection{XRD}

The diffractograms of the samples were recorded by $\mathrm{X}$-ray diffractometer ( $\mathrm{X}^{\prime}$ Pert Pro XRD, PANalytical, The Netherlands), which was operated at $40 \mathrm{kV}$ and $40 \mathrm{~mA}$ with $\mathrm{CuK} \alpha$ radiation $(\lambda=1.5406 \AA)$. The data were collected at scanning speed of $4.5^{\circ} \cdot \mathrm{min}^{-1}$ and $2 \theta$ range of $5-50^{\circ}$. Bragg equation was used to calculate the $d$ values of collagen:

$$
\mathrm{d}(\stackrel{\circ}{\mathrm{A}})=\frac{\lambda}{2 \sin \theta}
$$

where $\lambda$ is the $\mathrm{X}$-ray wavelength $\left(1.54^{\circ}\right)$ and $\theta$ is the Bragg diffraction angle.

\subsection{Amino Acid Analysis}

The samples were hydrolyzed in $6 \mathrm{M} \mathrm{HCl}$ at $110^{\circ} \mathrm{C}$ for $8 \mathrm{~h}$. After being vaporized, the residue was dissolved in $100 \mathrm{~mL}$ of $0.1 \mathrm{M} \mathrm{HCl}$ [22]. Then $50 \mu \mathrm{L}$ of the sample solution was analyzed using high-performance liquid chromatography (HPLC-MS/MS, Ultimate 3000-API 4000 Q TRAP, Thermo Fisher Scientific, Dreieich, Germany).

\subsection{Microscopy Characterisation}

The collagen solution (5-10 $\mu \mathrm{L}$ ) without acetic acid was poured into a 12-cm-diameter lyophilization dish and then freeze-dried. The morphology of the sample was imaged using SEM (S-4800, HITACHI, Tokyo, Japan), with an accelerating voltage of $5 \mathrm{kV}$. After being coated with $\mathrm{Pd}$, the samples were observed at $400 \times$ and $800 \times$ magnifications.

\subsection{Thermal Stability}

The thermal stability of the samples was measured using a differential scanning calorimeter (DSC2, Mettler-Toledo corp., Zurich, Switzerland) under a nitrogen atmosphere with a flow rate of $100 \mathrm{~mL} \mathrm{~min}{ }^{-1}$. The samples were dissolved in $0.4 \mathrm{M}$ acetic acid at the ratio of 1:40 $(w / v)$ for $48 \mathrm{~h}$ at $4{ }^{\circ} \mathrm{C}$. The solution $(5 \mathrm{~mL}-10 \mathrm{~mL})$ was placed into aluminium crucible, and then scanned over the range of $20-70{ }^{\circ} \mathrm{C}$ at a heating rate of $1{ }^{\circ} \mathrm{C} / \mathrm{min}$. The empty aluminium crucible was used for reference. The maximum transition temperature 
$\left(\mathrm{T}_{\max }\right)$ was obtained from the DSC thermogram, and the enthalpy of denaturation $(\Delta \mathrm{H})$ was calculated from the area of the corresponding endothermic peak.

\subsection{Solubility}

\subsubsection{Effect of $\mathrm{pH}$}

The effect of $\mathrm{pH}$ on collagen solubility was determined using the method described by Chen et al. (2016) [18], with bovine serum albumin (BSA) as the protein standard. The samples were dissolved in $0.5 \mathrm{M}$ acetic acid at the final concentration of $0.2 \mathrm{mg} / \mathrm{mL}$. The $\mathrm{pH}$ of the sample solution ( $5 \mathrm{~mL}$ ) was adjusted from 2 to 10 , with $6 \mathrm{M} \mathrm{HCl}$ or $6 \mathrm{M} \mathrm{NaOH}$. Then, the sample solutions were mixed with distilled water of the same $\mathrm{pH}$ until the solution volume reached $10 \mathrm{~mL}$. The relative solubility was calculated through comparison with the solubility obtained at the $\mathrm{pH}$ that exhibited the highest solubility.

Collagen solubility was determined at various $\mathrm{pH}$ levels using the method described by Chen et al. (2016) [18] with slight modifications. The samples were dissolved in $0.5 \mathrm{M}$ acetic acid at a concentration of $0.3 \%(w / v)$ with gentle stirring at $4{ }^{\circ} \mathrm{C}$ for $12 \mathrm{~h}$. The collagen solution $(8 \mathrm{~mL})$ was placed in a centrifuge tube. Then, the $\mathrm{pH}$ was adjusted to different levels, ranging from 2 to 10, using $6 \mathrm{M} \mathrm{HCl}$ or $6 \mathrm{M} \mathrm{NaOH}$. The final volume was brought to $10 \mathrm{~mL}$ by distilled water previously adjusted to the same $\mathrm{pH}$ as the collagen solution tested. The solutions were gently stirred at $4{ }^{\circ} \mathrm{C}$ for $30 \mathrm{~min}$ and left overnight. Next, the supernatants were collected after centrifugation for $30 \mathrm{~min}$ at $10,000 \times \mathrm{g}$. Protein content in the supernatant was calculated using the Lowry method (1951) [52], with BSA as the protein standard. The relative solubility was determined in comparison with that obtained at the $\mathrm{pH}$ level that provided the highest solubility.

\subsubsection{Effect of $\mathrm{NaCl}$}

The effect of $\mathrm{NaCl}$ on collagen solutions was measured in accordance with the method described by Chen et al. [18], BSA was used as standard. The samples were dissolved in $0.5 \mathrm{M}$ acetic acid at a concentration of $0.2 \mathrm{mg} / \mathrm{mL}$. The sample solution $(5 \mathrm{~mL})$ was mixed with $5 \mathrm{~mL}$ of a series of $\mathrm{NaCl}$ concentrations containing $0.5 \mathrm{M}$ acetic acid to obtain the final solutions with $\mathrm{NaCl}$ concentrations of $0 \%, 2 \%, 4 \%, 6 \%, 8 \%, 10 \%, 12 \%$, and $14 \%, w / v$. The protein content was measured as described in Section 4.8.1, and the relative solubility was calculated using the solution with final $\mathrm{NaCl}$ concentrations of $0 \%(w / v)$ as a control.

\subsection{Rheological Properties}

The rheological properties of collagen were measured by a rheometer (MCR 302, Anton Paar, Graz, Austria) using a stainless-steel cone/plate geometry $\left(0.5^{\circ}\right.$ cone angle, $60 \mathrm{~mm}$ cone diameter, gap of $57 \mu \mathrm{m})$. The sample $(20 \mathrm{mg} / \mathrm{mL})$ was dissolved in $0.5 \mathrm{M}$ acetic acid and then assessed by dynamic frequency sweeps with a constant strain of $30 \%$. The elastic modulus $\left(G^{\prime}\right)$ and viscous modulus $\left(G^{\prime \prime}\right)$ of the sample were measured as functions of the frequency range of 0.01 to $10 \mathrm{~Hz}$, at $25^{\circ} \mathrm{C}$ [41]. Each sample was equilibrated for $10 \mathrm{~min}$ before measurement.

\subsection{Cell Compatibility and Cell Morphology}

The cytotoxicity of collagen to the HaCaT and MC3T3-E1 cells was evaluated using a CCK-8 assay with some modifications as described by Sripriya et al. (2015) [53]. The collagen samples were dissolved in distilled water at a concentration of $5 \mathrm{mg} / \mathrm{mL}$. The bottom of the 96-well plates was coated with the collagen solutions $(5 \mathrm{mg} / \mathrm{mL})$ and dried under a laminar airflow hood followed by UV disinfection. The cells were seeded with a density of $1 \times 10^{4}$ cells per well and then incubated at $37^{\circ} \mathrm{C}$ in a humidified atmosphere with $5 \% \mathrm{CO}_{2}$ for $24 \mathrm{~h}$ and $48 \mathrm{~h}$. The CCK-8 solution was added to each well, and incubation was continued for $1.5 \mathrm{~h}$. The absorbance values were measured at $450 \mathrm{~nm}$ (Mithras² LB 943, Berthold, Germany), and the uncoated wells were used as controls. The cell viability was 
calculated using Equation (2). Subsequently, the morphology of each group was observed under an inverted microscope (ECLIPSE Ti, Nikon, Japan).

$$
\text { Cell viability }(\%)=\left(1-\frac{\text { absorbance of treatment }}{\text { absorbance of control }}\right) \times 100 \%
$$

\subsection{Statistical Analyses}

The analysis of variance (ANOVA) was performed using SPSS Version 17.0 software (IBM SPSS Statistics, Ehningen, Germany), and a value of $p<0.05$ was used to indicate a significant deviation. The different letters indicate significant differences between the samples.

\section{Conclusions}

Collagen was successfully isolated from lizardfish by-product scales by using acid and pepsin extraction methods with yields of $4.2 \%$ and $4.7 \%$ (based on the dry weight). The analysis of SDS-PAGE and UV indicated that both ASC and PSC were type I collagen. The FTIR and CD spectra of ASC and PSC were similar; the collagen maintained the triple-helical structures well, indicating that the triple-helix structure of collagen was not disrupted by pepsin digestion. The two types of collagen exhibited multilayer overlapping and porous sheet-like microstructure under SEM. The analysis of the amino acid structure showed that the ASC and PSC had high amino acid contents at 237 residues/1000 residues and 236 residues/1000 residues, respectively. Solubility tests showed that ASC and PSC exhibited high solubility in the acidic $\mathrm{pH}$ ranges $(\mathrm{pH} 1-4)$ and low $\mathrm{NaCl}$ levels $(1-6 \%, w / v)$. Moreover, the ASC from lizardfish scales exhibited higher $\mathrm{T}_{\max }\left(43.2^{\circ} \mathrm{C}\right)$ compared to rat tail collagen $\left(39.4^{\circ} \mathrm{C}\right)$ and calf skin collagen $\left(35^{\circ} \mathrm{C}\right)$, indicating its potential as an alternative to collagen of terrestrial source. A dynamic rheological examination indicated that the preparation method may affect the viscoelasticity of the collagen, and that PSC exhibited better viscoelasticity than ASC. Both ASC and PSC were not toxic to the HaCaT and MC3T3E1 cells, and the relative cell viability of ASC was higher than that of PSC during the $48 \mathrm{~h}$ of cell culture. Overall, the results suggest that lizardfish scales ASC may be considered a potential alternative to terrestrial collagen for further use in the biomedical area.

Author Contributions: J.C. conceptualization, validation, resources, writing —original draft preparation, writing - review and editing, supervision, project administration, funding acquisition; Y.L. conceptualization, methodology, formal analysis, data curation, writing-original draft preparation; G.W. conceptualization, methodology, software, formal analysis, data curation. All authors have read and agreed to the published version of the manuscript.

Funding: This research was funded by the National Natural Science Foundation of China, grant number 42076120, 41676129, 41106149; Scientific Research Foundation of the Third Institute of Oceanography, SOA, grant number 2019010; the Marine Economic Innovation \& Development Project of Beihai, grant number Bhsfs008. The APC was funded by the National Natural Science Foundation of China, grant number 42076120.

Institutional Review Board Statement: Not applicable.

Informed Consent Statement: Not applicable.

Data Availability Statement: All data supporting the conclusions of this article are included in this article.

Acknowledgments: The authors would like to thank Jianlin He from the Third Institute of Oceanography, Ministry of Natural Resources, for his technical help for cell compatibility and cell morphology analysis.

Conflicts of Interest: The authors declare no conflict of interest. 


\section{References}

1. Ahmed, R.; Haq, M.; Chun, B.-S. Characterization of marine derived collagen extracted from the by-products of bigeye tuna (Thunnus obesus). Int. J. Biol. Macromol. 2019, 135, 668-676. [CrossRef]

2. Lee, J.M.; Suen, S.K.Q.; Ng, W.L.; Ma, W.C.; Yeong, W.Y. Bioprinting of Collagen: Considerations, Potentials, and Applications. Macromol. Biosci. 2021, 21, e2000280. [CrossRef]

3. Wang, S.; Zhao, J.; Chen, L.; Zhou, Y.; Wu, J. Preparation, isolation and hypothermia protection activity of antifreeze peptides from shark skin collagen. LWT 2014, 55, 210-217. [CrossRef]

4. Hong, H.; Fan, H.; Roy, B.C.; Wu, J. Amylase enhances production of low molecular weight collagen peptides from the skin of spent hen, bovine, porcine, and tilapia. Food Chem. 2021, 352, 129355. [CrossRef]

5. Davison-Kotler, E.; Marchall, W.S.; Garcia-Gareta, E. Sources of collagen for biomaterials in skin wound healing. Bioengineering 2019, 6, 56. [CrossRef]

6. Faralizadeh, S.; Rahimabadi, E.Z.; Bahrami, S.H.; Hasannia, S. Extraction, characterization and biocompatibility evaluation of collagen from silver carp (Hypophthalmichthys molitrix) skin by-product. Sustain. Chem. Pharm. 2021, 22, 100454. [CrossRef]

7. Bak, S.Y.; Lee, S.W.; Choi, C.H.; Kim, H.W. Assessment of the influence of acetic acid residue on type I collagen during iso-lation and characterization. Materials 2018, 11, 2518. [CrossRef]

8. Rastian, Z.; Pütz, S.; Wang, Y.J.; Kumar, S.; Fleissner, F.; Weidner, T.; Parekh, S.H. Type i collagen from jellyfish catostylus mosaicus for biomaterial applications. ACS Biomater. Sci. Eng. 2018, 4, 2115-2125. [CrossRef]

9. Subhan, F.; Ikram, M.; Shehzad, A.; Ghafoor, A. Marine Collagen: An Emerging Player in Biomedical applications. J. Food Sci. Technol. 2015, 52, 4703-4707. [CrossRef]

10. Cruz-López, H.; Rodríguez-Morales, S.; Enríquez-Paredes, L.M.; Villarreal-Gómez, L.J.; Olivera-Castillo, L.; Cortes-Santiago, Y.; YadiraLópez, L.M. Comparison of collagen characteristic from the skin and swim bladder of gulf corvina (Cynoscion othonopterus). Tissue Cell 2021, 72, 101593. [CrossRef]

11. Addad, S.; Exposito, J.-Y.; Faye, C.; Ricard-Blum, S.; Lethias, C. Isolation, Characterization and Biological Evaluation of Jellyfish Collagen for Use in Biomedical Applications. Mar. Drugs 2011, 9, 967-983. [CrossRef]

12. Tziveleka, L.-A.; Ioannou, E.; Tsiourvas, D.; Berillis, P.; Foufa, E.; Roussis, V. Collagen from the marine sponges Axinella can-nabina and Suberites carnosus: Isolation and morphological, biochemical, and biophysical characterization. Mar. Drugs 2017, 15, 152. [CrossRef]

13. Coppola, D.; Lauritano, C.; Esposito, F.P.; Riccio, G.; Rizzo, C.; de Pascale, D. Fish Waste: From problem to valuable resource. Mar. Drugs 2021, 19, 116. [CrossRef]

14. Jafari, H.; Lista, A.; Siekapen, M.M.; Ghaffari-Bohlouli, P.; Nie, L.; Alimoradi, H.; Shavandi, A. Fish Collagen: Extraction, characterization, and applications for biomaterials engineering. Polymers 2020, 12, 2230. [CrossRef]

15. Li, D.; Gao, Y.; Wang, Y.; Yang, X.; He, C.; Zhu, M.; Zhang, S.; Mo, X. Evaluation of biocompatibility and immunogenicity of micro/nanofiber materials based on tilapia skin collagen. J. Biomater. Appl. 2019, 33, 1118-1127. [CrossRef]

16. Caruso, G.; Floris, R.; Serangeli, C.; Di Paola, L. Fishery Wastes as a Yet Undiscovered Treasure from the Sea: Biomolecules Sources, Extraction Methods and Valorization. Mar. Drugs 2020, 18, 622. [CrossRef]

17. Liu, Y.; Ma, D.; Wang, Y.; Qin, W. A comparative study of the properties and self-aggregation behavior of collagens from the scales and skin of grass carp (Ctenopharyngodon idella). Int. J. Biol. Macromol. 2018, 106, 516-522. [CrossRef]

18. Chen, J.; Li, L.; Yi, R.; Xu, N.; Gao, R.; Hong, B. Extraction and characterization of acid-soluble collagen from scales and skin of tilapia (Oreochromis niloticus). LWT 2016, 66, 453-459. [CrossRef]

19. Tangguh, H.L.; Prahasanti, C.; Ulfah, N.; Krismariono, A. Characterization of pepsin-soluble collagen extracted from gourami (Osphronemus goramy) scales. Niger. J. Clin. Pract. 2021, 24, 89-92. [CrossRef]

20. Li, L.Y.; Zhao, Y.Q.; He, Y.; Chi, C.F.; Wang, B. Physicochemical and antioxidant properties of acid- and pepsin-soluble col-lagens from the scales of miiuy croaker (Miichthys miiuy). Mar. Drugs 2018, 16, 394. [CrossRef]

21. Pal, G.K.; Suresh, P.V. Physico-chemical characteristics and fibril-forming capacity of carp swim bladder collagens and ex-ploration of their potential bioactive peptides by in silico approaches. Int. J. Biol. Macromol. 2017, 101, 304-313. [CrossRef]

22. Sun, L.; Li, B.; Song, W.; Si, L.; Hou, H. Characterization of Pacific cod (Gadus macrocephalus) skin collagen and fabrication of collagen sponge as a good biocompatible biomedical material. Process. Biochem. 2017, 63, 229-235. [CrossRef]

23. Li, C.; Song, W.; Wu, J.; Lu, M.; Zhao, Q.; Fang, C.; Wang, W.; Park, Y.-D.; Qian, G.-Y. Thermal stable characteristics of acid- and pepsin-soluble collagens from the carapace tissue of Chinese soft-shelled turtle (Pelodiscus sinensis). Tissue Cell 2020, 67, 101424. [CrossRef]

24. Zhang, J.; Duan, R.; Ye, C.; Konno, K. Isolation and characterization of collagens from scale of silver carp (hypophthalmichthys molitrix). J. Food Biochem. 2010, 34, 1343-1354. [CrossRef]

25. Chen, J.; Li, M.; Yi, R.; Bai, K.; Wang, G.; Tan, R.; Sun, S.; Xu, N. Electrodialysis extraction of pufferfish skin (Takifugu flavidus): A promising source of collagen. Mar. Drugs 2019, 17, 25. [CrossRef]

26. Sun, L.; Hou, H.; Li, B.; Zhang, Y. Characterization of acid- and pepsin-soluble collagen extracted from the skin of Nile tilapia (Oreochromis niloticus). Int. J. Biol. Macromol. 2017, 99, 8-14. [CrossRef]

27. Zhu, S.C.; Yuan, Q.J.; Yang, M.T.; You, J.; Yin, T.; Gu, Z.P.; Hu, Y.; Xiong, S.B. A quantitative comparable study on multi-hierarchy conformation of acid and pepsin-solubilized collagens from the skin of grass carp (Ctenopharyngodon idella). Mater. Sci. Eng. C 2018, 96, 446-457. [CrossRef] 
28. Liu, A.; Zhang, Z.; Hou, H.; Zhao, X.; Li, B.; Zhao, T.; Liu, L. Characterization of Acid- and Pepsin-Soluble Collagens from the Cuticle of Perinereis nuntia (Savigny). Food Biophys. 2018, 13, 274-283. [CrossRef]

29. Chen, J.; Li, J.; Li, Z.; Yi, R.; Shi, S.; Wu, K.; Li, Y.; Wu, S. Physicochemical and Functional Properties of Type I Collagens in Red Stingray (Dasyatis akajei) Skin. Mar. Drugs 2019, 17, 558. [CrossRef]

30. Tang, Y.; Jin, S.; Li, X.; Li, X.; Hu, X.; Chen, Y.; Huang, F.; Yang, Z.; Yu, F.; Ding, G. Physicochemical properties and biocompatibility evaluation of collagen from the skin of giant croaker (Nibea japonica). Mar. Drugs 2018, 16, 222. [CrossRef]

31. Sun, B.; Li, C.; Mao, Y.; Qiao, Z.; Jia, R.; Huang, T.; Xu, D.; Yang, W. Distinctive characteristics of collagen and gelatin extracted from Dosidicus gigas skin. Int. J. Food Sci. Technol. 2021, 56, 3443-3454. [CrossRef]

32. Song, Z.; Liu, H.; Chen, L.; Chen, L.; Zhou, C.; Hong, P.; Deng, C. Characterization and comparison of collagen extracted from the skin of the Nile tilapia by fermentation and chemical pretreatment. Food Chem. 2021, 340, 128139. [CrossRef]

33. Chen, X.H.; Jin, W.G.; Chen, D.J.; Dong, M.R.; Xin, X.; Li, C.Y.; Xu, Z. Collagens made from giant salamander (Andrias da-vidianus) skin and their odorants. Food Chem. 2021, 361, 130061. [CrossRef]

34. Akram, A.N.; Zhang, C. Effect of ultrasonication on the yield, functional and physicochemical characteristics of collagen-II from chicken sternal cartilage. Food Chem. 2020, 307, 125544. [CrossRef]

35. Ma, Y.H.; Teng, A.G.; Zhang, K.X.; Zhang, K.; Zhao, H.Y.; Duan, S.M.; Liu, S.Z.; Guo, Y.; Wang, W.H. A top-down approach to improve collagen film's performance: The comparisons of macro, micro and nano sized fibers-sciencedirect. Food Chem. 2020, 309, 125624. [CrossRef]

36. Guo, S.J.; He, L.L.; Yang, R.Q.; Chen, B.Y.; Xie, X.D.; Jiang, B.; Tian, W.D.; Ding, Y. Enhanced effects of electrospun collagen-chitosan nanofiber membranes on guided bone regeneration. J. Biomater. Sci. Polym. Ed. 2020, 31, 155-168. [CrossRef]

37. Pal, G.K.; Suresh, P. Comparative assessment of physico-chemical characteristics and fibril formation capacity of thermostable carp scales collagen. Mater. Sci. Eng. C 2017, 70, 32-40. [CrossRef]

38. Kaewdang, O.; Benjakul, S.; Kaewmanee, T.; Kishimura, H. Characteristics of collagens from the swim bladders of yellowfin tuna (Thunnus albacares). Food Chem. 2014, 155, 264-270. [CrossRef]

39. Matmaroh, K.; Benjakul, S.; Prodpran, T.; Encarnacion, A.B.; Kishimura, H. Characteristics of acid soluble collagen and pepsin soluble collagen from scale of spotted golden goatfish (Parupeneus heptacanthus). Food Chem. 2011, 129, 1179-1186. [CrossRef]

40. Wang, S.-S.; Yu, Y.; Sun, Y.; Liu, N.; Zhou, D.-Q. Comparison of physicochemical characteristics and fibril formation ability of collagens extracted from the skin of farmed river puffer (Takifugu obscurus) and Tiger Puffer (Takifugu rubripes). Mar. Drugs 2019, 17, 462. [CrossRef]

41. Zhou, C.S.; Li, Y.H.; Yu, X.J.; Yang, H.; Ma, H.L.; Yagoub, A.E.A.; Cheng, Y.; Hu, J.L.; Otu, P.N.Y. Extraction and characterization of chicken feet soluble collagen. LWT-Food Sci. Technol. 2016, 74, 145-153. [CrossRef]

42. Chuaychan, S.; Benjakul, S.; Kishimura, H. Characteristics of acid- and pepsin-soluble collagens from scale of seabass (Lates calcarifer). LWT Food Sci. Technol. 2015, 63, 71-76. [CrossRef]

43. Zhang, Y.; Liu, W.; Li, G.; Shi, B.; Miao, Y.; Wu, X. Isolation and partial characterization of pepsin-soluble collagen from the skin of grass carp (Ctenopharyngodon idella). Food Chem. 2007, 103, 906-912. [CrossRef]

44. Zhong, M.; Chen, T.; Hu, C.Q.; Ren, C.H. Isolation and characterization of collagen from the body wall of sea cucumber sti-chopus monotuberculatus. J. Food Sci. 2015, 80, C671-C679. [CrossRef] [PubMed]

45. Chen, J.; Liu, Y.; Wang, G.; Sun, S.; Liu, R.; Hong, B.; Gao, R.; Bai, K. Processing optimization and characterization of angiotensinI-converting enzyme inhibitory peptides from lizardfish (Synodus macrops) scale gelatin. Mar. Drugs 2018, 16, 228. [CrossRef]

46. Nalinanon, S.; Benjakul, S.; Kishimura, H. Collagens from the skin of arabesque greenling (Pleurogrammus azonus) solubilized with the aid of acetic acid and pepsin from albacore tuna (Thunnus alalunga) stomach. J. Sc. Food Agr. 2010, 90, 1492-1500. [CrossRef]

47. Oliveira, V.D.M.; Assis, C.R.D.; Costa, B.D.A.M.; Neri, R.C.D.A.; Monte, F.T.D.; Freitas, H.M.S.D.C.V.; França, R.C.P.; Santos, J.F.; Bezerra, R.D.S.; Porto, A.L.F. Physical, biochemical, densitometric and spectroscopic techniques for characterization collagen from alternative sources: A review based on the sustainable valorization of aquatic by-products. J. Mol. Struct. 2021, 1224, 129023. [CrossRef]

48. Chen, Y.; Jin, H.; Yang, F.; Jin, S.; Liu, C.; Zhang, L.; Huang, J.; Wang, S.; Yan, Z.; Cai, X.; et al. Physicochemical, antioxidant properties of giant croaker (Nibea japonica) swim bladders collagen and wound healing evaluation. Int. J. Biol. Macromol. 2019, 138, 483-491. [CrossRef]

49. Jongjareonrak, A.; Benjakul, S.; Visessanguan, W.; Nagai, T.; Tanaka, M. Isolation and characterisation of acid and pep-sinsolubilised collagens from the skin of brownstripe red snapper (Lutjanus vitta). Food Chem. 2005, 93, 475-484. [CrossRef]

50. Kiew, P.L.; Mashitah, M.D. Isolation and characterization of collagen from the skin of Malaysian catfish (Hybrid Clarias sp.). J. Korean Soc. Appl. Biol. Chem. 2013, 56, 441-450. [CrossRef]

51. Laemmli, U.K. Cleavage of structural proteins during the assembly of the head of bacteriophage T4. Nature 1970, 227, 680-685. [CrossRef] [PubMed]

52. Lowry, O.H.; Rosebrough, N.J.; Farr, A.L.; Randall, R.J. Protein measurement with the Folin phenol reagent. J. Biol. Chem. 1951, 193, 265-275. [CrossRef]

53. Sripriya, R.; Kumar, R. A Novel Enzymatic Method for Preparation and Characterization of Collagen Film from Swim Bladder of Fish Rohu (Labeo rohita). Food Nutr. Sci. 2015, 6, 1468-1478. [CrossRef] 